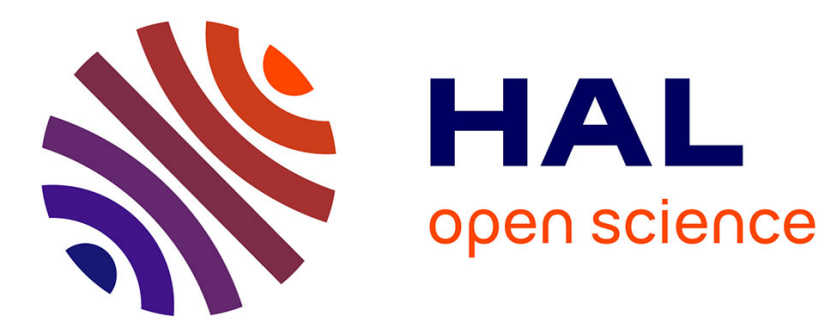

\title{
COMPETITIVE ADVERTISING WITHIN STORE FLYERS: A WIN-WIN STRATEGY?
}

Aîda Mimouni, Ouidade Sabri-Zaaraoui, Béatrice Parguel

\section{To cite this version:}

Aîda Mimouni, Ouidade Sabri-Zaaraoui, Béatrice Parguel. COMPETITIVE ADVERTISING WITHIN STORE FLYERS: A WIN-WIN STRATEGY?. Journal of Retailing \& Consumer Services, 2010, 17 (6), pp.478-486. halshs-00634439

\section{HAL Id: halshs-00634439 \\ https://shs.hal.science/halshs-00634439}

Submitted on 13 Jan 2012

HAL is a multi-disciplinary open access archive for the deposit and dissemination of scientific research documents, whether they are published or not. The documents may come from teaching and research institutions in France or abroad, or from public or private research centers.
L'archive ouverte pluridisciplinaire HAL, est destinée au dépôt et à la diffusion de documents scientifiques de niveau recherche, publiés ou non, émanant des établissements d'enseignement et de recherche français ou étrangers, des laboratoires publics ou privés. 


\title{
COMPETITIVE ADVERTISING WITHIN STORE FLYERS: A WIN-WIN STRATEGY?
}

\author{
Aîda MIMOUNI CHAABANE** \\ Associate Professor, University of Cergy-Pontoise (THEMA Research Center) \\ IUT Techniques de Commercialisation \\ 34, boulevard Bergson 95200 Sarcelles \\ Tel.: +33134382628/ Fax: +33134382627 \\ aida.mimouni@u-cergy.fr
}

Ouidade SABRI

Associate Professor, IAE de Paris (GREGOR Research Center)

21, rue Broca 75005 Paris

ouidade.sabri@yahoo.fr

\section{Béatrice PARGUEL}

Assistant Professor, University of Paris-Dauphine (DRM Research Center) and IAE Gustave Eiffel (IRG Research Center)

Place du Maréchal de Lattre de Tassigny 75016 Paris

beatrice.parguel@gmail.com

\footnotetext{
* Corresponding author
} 


\title{
Competitive advertising within store flyers: a win-win strategy?
}

\begin{abstract}
This study investigates the effect of competitive advertising within store flyers on both manufacturers and retailers. Prior research implies that competitive advertising may be detrimental for manufacturers and beneficial for retailers. Findings from an intersubject experiment that uses various familiar and unfamiliar competing brands confirm that store flyers' competitive advertising improves consumers' perceptions of the variety of the retailer's assortment, which has a positive impact on intentions to visit the store and buy. However, increasing the number of competing brands does not harm manufacturers; rather, it enhances recognition of brands, especially for well-known brands. This article concludes with a discussion of the theoretical and managerial implications of these findings for the design of store flyers.
\end{abstract}

Keywords: store flyers; competitive advertising; brand recognition; perceived variety of the retailer's assortment. 


\section{Introduction}

Store flyers, a specific form of feature advertising, are printed advertisements used by retailers to present their assortment, promote new products and stores, and communicate about price specials (Miranda and Konya, 2006; Pieters et al., 2007). They also represent increasingly important portions of retailers' communication budgets. In 2002, U.S. retailers spent $\$ 8$ billion on store flyers and feature advertising inserted in newspapers, which represented approximately half of their total advertising spending (Bodapati and Srinivasan, 2006). In France, the figures have been even higher. In 2006, retailers distributed 13 million store flyers that accounted for $66 \%$ of their communication investments (Aubril and Puget, 2007).

Both manufacturers and retailers attribute a strategic role to store flyers.

Manufacturers advertise in store flyers to achieve point-of-sale communications and a good in-store promotion (e.g., aisle-end displays, product displays). Furthermore, store flyers enhance manufacturers' brand purchase and choice rates (Moriarty, 1983; Blattberg and Neslin, 1990). As for retailers, empirical evidence indicates that store flyers build store traffic (Burton et al., 1999; Volle, 2001; Gijsbrechts et al., 2003; Miranda and Konya, 2007), increase purchases of advertised and unadvertised products, and increase the amount consumers spend on these products (Burton et al., 1999), which implies a favorable effect on profits and margins (Volle, 2001). Moreover, store flyers offer a flexible means to convey a good price positioning, which is a key attribute of the retailer's store image in price-sensitive settings (Volle, 2001). Store flyers also help retailers communicate about the variety present in their store assortment (Arnold et al., 2001). Finally, retailers rely on store flyers as a source of income, earned from the fees charged to manufacturers to appear in them (Gijsbrechts et al., 2003; Pieters et al., 2007). 
To reach these various objectives, retailers might increase the number of promoted products presented on the same ad display page (Leterrier, 2003). However, doing so means they increase the likelihood that competing brands might advertise simultaneously, which would reduce the effectiveness of store flyers for manufacturers. This study therefore raises a key question: What is the effect of competitive advertising on store flyers' effectiveness? This issue is all the more relevant in the case of out-of-store flyers (e.g., printed or inserted in newspapers, direct mail flyers) relative to in-store flyers. There is a time lag between exposure to out-of-store flyers and the purchase opportunity, so increasing the number of competing brands in a flyer may affect consumers' memory performance at the point of purchase, more so than it would for in-store flyers. Furthermore, if they really want to boost traffic and attract new customers, retailers should be more interested in the efficiency of outof-store flyers.

Investigating the impact of competitive advertising contained within store flyers thus represents a hot topic for both manufacturers and retailers. If increasing the number of competing brands has negative effects on brand awareness, manufacturers' investment in store flyers might be inefficient or even pointless. To achieve a positive return on their investment, they would need to resort to other strategies - such as buying an exclusive page to promote their own brands. Retailers also need to guarantee the success of exposures in store flyers by convincing manufacturers — who largely finance these flyers — of the positive effects on their brands and sales.

\section{Conceptual framework}

Competitive advertising occurs when a target brand appears with advertisements from other, competitive brands. It might result when advertisements present the same contextual elements, such as pictures, colors, or brand promise (Burke and Srull, 1988; Keller, 1991; 
Kumar, 2000; Kumar and Krishnan, 2004; Pieters et al., 2007; Zhang et al., 2009), or contain directly competing brands (Keller, 1987; Kent and Allen, 1994; Kent and Kellaris, 2001; Kumar and Krishnan, 2004; Laroche et al., 2006; Danaher, 2008).

Pieters et al. (2007) and Zhang et al. (2009) have examined the effect of competitive advertisements in store flyers on attention and sales. Attention to a whole page decreases with contextual competitive advertising (Pieters et al., 2007). That is, when the design elements (i.e., brand, pictorial, text, price, promotion) of the ads are similar, consumers pay less attention to them. Furthermore, contextual competitive advertising is detrimental to sales, because it decreases attention to the promoted brands (Zhang et al., 2009). However, to our knowledge, no research considers the issue of directly competing brands in store flyers and their likely effect on brand memory. Prior studies also mainly adopt the manufacturer's point of view, even though the communication in store flyers represents two sources, retailers and manufacturers, who pursue different objectives. Retailers advertise a bundle of offers that are simultaneously attractive and seek greater impacts of the display page as a whole; manufacturers are interested only in the attractiveness of their specific offer. As a result, competitive advertising within store flyers deserves further investigation and from dual perspectives.

\subsection{Effects of competitive advertising within store flyers on manufacturers}

Store flyers represent a special form of informative advertising that increases sales by attracting customers' attention (Burton et al., 1999; Chandon et al., 2000; Zhang et al., 2009). Accordingly, manufacturers that aim for positive outcomes of advertising in store flyers must first ensure that consumers who view the flyer remember the appropriate brand information.

The effect of exposure to competitive advertising is a well-documented topic among advertising researchers (Keller, 1987, 1991; Burke and Srull, 1988; Kent and Allen, 1994; 
Kumar, 2000; Kent and Kellaris, 2001; Kumar and Krishnan, 2004; Laroche et al., 2006), who find that the number of competing brands has a negative effect on memory, due to interference. Interference is "the process by which our ability to recollect some information is hindered by our exposure to some other information" (Kumar, 2000, p. 155). Learning new information about a stimulus may reduce recall of older information stored in the memory. Additional learned attribute information about competing brands also results in a multiplication of links between the information and brands, which weakens the association between the brands and their advertising memory traces. In such conditions, target information may become inaccessible or confused (Burke and Srull, 1988; Keller, 1991).

As a special form of advertising (Burton et al., 1999), store flyers should be subject to similar findings. They naturally present denser information than most advertising exposure situations (Gijsbrechts et al., 2003). Because the various brands try to attract attention using similar economic-oriented attributes, there is little distinction between the competing brands and no salient cue that consumers can use to enhance their recall of one particular brand (Pieters et al., 2007). On the contrary, print advertising usually presents brands on separate pages, to allow them to benefit from sufficient space to communicate their promises in a creative and differentiated way. The effects of competitive advertising within store flyers on memory therefore may be more important than those pertaining to general print competitive advertising.

However, exposure to promoted brands in general print advertising can be controlled by consumers. A consumer involved in reading an article can skip an advertisement and avoid (in real-life settings) exposure to that advertisement. In contrast, consumers generally choose to be exposed to advertisements in store flyers, especially direct mail flyers. Because they are likely more involved in this situation, they may process the information more extensively. 
Consequently, we expect that store flyers are more resistant to the potential negative effects of competitive advertising.

This discussion in turn implies that the effects of competitive advertising within store flyers may be different from and more complex than those of advertising in general and print advertising in particular. Considering that previous work on competitive advertising and interference points to and empirically supports the idea of a negative relationship between the number of competing brands and memory, we lean toward the first argument and postulate the following hypothesis:

\section{H1: Exposure to competitive advertising within store flyers has a negative effect on} memory for the (a) brand and (b) promotional offer.

Brand familiarity — defined as the consumer's level of direct and indirect experience with a product (Alba and Hutchinson, 1987)—plays an important role for competitive advertising effects (Kent and Allen, 1994; Kent and Kellaris, 2001; Kumar and Krishnan, 2004; Laroche et al., 2006). According to previous research, attention to both familiar and unfamiliar brands is negatively affected by competitive advertising (Kumar and Krishnan, 2004; Laroche et al., 2006), but this effect is minor for well-known brands (Kent and Allen, 1994; Kent and Kellaris, 2001). Messages from competing brands generate less confusion because they benefit from a strong memory structure and richly coded associations. Thus, consumers may be more willing to pay attention to advertisements about brands with which they are familiar and retain more information about these brands (Keller, 1987; Kent and Allen, 1994; Laroche et al., 2006). Keller (1987) notes, for example, that consumers engage in more extensive and complete processing of advertising for brands they already know well. This processing also may enhance the link between a familiar brand and the advertisement 
and ease information retrieval. Consequently, brand recall and recognition should be higher for familiar than for unfamiliar brands. This discussion leads to the following hypothesis:

H2: Brand familiarity reduces the negative effect of exposure to competitive advertising within store flyers on memory for the (a) brand and (b) promotional offer.

\subsection{Effects of competitive advertising within store flyers on retailers}

To drive traffic and increase sales, retailers need to ensure that consumers' perceptions of their assortment is positive (Oppewal and Timmermans, 1997). Literature on assortment perceptions shows that it depends on the space allocated to a given product category (Kahn and Wansink, 2004), as well as category attributes (Broniarczyk et al., 1998). The more that the attributes in a product category are distinct, the more consumers perceive the assortment as varied (van Harpen and Pieters, 2002). Category attributes include brands (Boatwright and Nunes, 2001), scent (Boatwright and Nunes, 2001), color, and size (van Harpen and Pieters, 2002). In store flyers, competitive advertising means that many brands help convey an image of variety. In the absence of any other information about the store, the consumer should infer an image of assortment variety for the retailer as a whole. According to the heuristics framework (Tversky and Kahneman, 1974), when people face uncertainty and/or complexity, they rely on heuristics (i.e., elementary rules) to simplify their decision-making process. To manage store flyers' complexity and deal with their limited cognitive ability, consumers may use the perceived attractiveness of the assortment in the store flyer as a salient cue of the variety of the retailer's assortment (i.e., availability heuristic). Therefore, we propose:

H3: Exposure to competitive advertising within store flyers has a positive effect on perceived variety of the retailer's assortment.

Finally, a recent meta-analysis (Pan and Zinkhan, 2006) shows that offering a varied assortment influences shoppers' behavioral intentions (i.e., intentions to visit the store and 
buy). Consumers choose to patronize stores that offer a more varied assortment, because those stores are more likely to offer products that meet the consumers' needs. Because we predict that perceived variety of the retailer's assortment can be influenced by competitive advertising within store flyers (H3), we also expect it may play a mediating role for intentions to visit the store and buy. Therefore, we posit:

H4: Perceived variety of the retailer's assortment mediates the relationship between exposure to competitive advertising within store flyers and intentions to (a) visit the store and (b) buy.

\section{Method}

To test these research hypotheses, we conduct an experiment that mixes within- and betweensubject designs.

\subsection{Experimental design}

The experiment manipulates two factors: competitive advertising within store flyers according to the number of competing brands $(0,2$, or 4$)$ and target brand familiarity (familiar versus unfamiliar). The condition with four competing brands is consistent with the results of our preliminary study of various retailers' store flyers, which showed that French customers encounter up to five competing brands on one store flyer page. All brands (familiar and unfamiliar, target and competing) are real brands. To enhance the external validity, we used two product categories: juice and detergent. Manufacturers in both these categories often resort to promotions, and customers frequently purchase these products.

3.1.1. Design. Similar to Keller (1991), we combined the competitive advertising-brand familiarity factors within and between subjects. Even if each participant views and assesses only one experimental condition (between), he or she will answer questions for two product 
categories (within), which provides greater external validity to the results without a subsequent increase in the total number of participants. This manipulation results in six conditions for each product class (Table 1): two conditions with no competing brands, two conditions with two competing brands, and two conditions with four competing brands.

[Insert Table 1 here]

3.1.2. Brand familiarity. Brands with different levels of familiarity in the French market represent each product category: Tropicana (familiar) and Vitalia (unfamiliar) for juice, and Ariel (familiar) and Dixan (unfamiliar) for detergent. These target brands were chosen on the basis of a pretest, in which 21 participants viewed pictures of different brands of juice (Tropicana, Vitalia, Joker, Cidou, Réa, and Pampryl) and detergent (Ariel, Dixan, Persil, Omo, Mir, and Skip). For each brand, the participants rated whether they were familiar/unfamiliar with, experienced/inexperienced with, and knowledgeable/not knowledgeable about the brands on a seven-point scale (Kent and Allen, 1994). This scale is reliable for both juice and detergent (Cronbach's alphas $=.93$ and .83 , respectively). Tropicana was the best known brand of juice, whereas Vitalia was the least known (means of familiarity $=5.75$ and 1.18 , respectively; $p<.01)$. In the detergent product class, Ariel was the best known brand, while Dixan was the least known (means of familiarity $=5.03$ and 1.00 , respectively; $p<.01)$. The other four competing brands are all familiar brands; most marketplace advertising involves familiar brands (Kent and Kellaris, 2001). Finally, the product line, product size, and container were consistent across the target brands: a one-liter bottle for orange juice and a three-liter container for liquid detergent.

\subsection{Experimental stimuli}


In line with real-world practices, each condition in the experiment featured a five-page extract from a store flyer. There was no indication of the retailer's name, to control for potential store and retailer name familiarity effects.

3.2.1. Store flyer layout. As in real exposure settings in France, each page presented a specific product theme. The juice brands appeared in the sugar and fine food theme, whereas the detergent brands were presented within the home care theme. Page 1 was the cover page. Pages 2 and 5 presented either the sugar and fine food or the home care themes, whereas page 3 contained salted fine foods and page 4 contained the hygiene theme. Each page of the store flyer proposed various promotional offers for seven different brands (target, competing when relevant, and distracter), consistent with French retail practices (Leterrier, 2003). This number remained constant across all six conditions. In conditions with competing brands, we dropped the promotions for other brands. For example, in the "no competing familiar brands" condition, respondents saw a promotion for Tropicana and six other brands (Lactel, Prince, Choco Pops, Lindt, Bonne Maman, and Velours Noir). In the "two competing familiar brands" condition, the Lactel and Prince promotions were replaced by those for Joker and Cidou. In the "four competing familiar brands" condition, two other brands (Choco Pops and Lindt) were replaced by Réa and Pampryl. The advertisement for each product provided a picture of the promoted product, the brand name, the promotional technique, and the value and prices before and after the promotion (see an example in Appendix 1).

3.2.2. Promotions. Promotional offers for target and competing brands use monetary mechanism but different techniques (e.g., price discounts, bundling). We use monetary mechanisms because they are the most commonly used by retailers and manufacturers (contained in more than $90 \%$ of the offers presented in store flyers in 2008 , according to 
LeSiteMarketing Institute). To avoid contextual interference due to similarities in the contextual elements (e.g., color, size, text, promotion), the target brands and the competing brands employed distinct promotional techniques. For example, Tropicana's promotion consisted of a two-bottle bundle without a price discount, whereas Réa offered a 15\% discount on a bundle of four bottles, Joker provided a $15 \%$ discount on a bundle of two bottles, and Cidou and Pampryl did not offer any price discount. Finally, to control for differences due to promotional advantage, the target familiar and unfamiliar brands also used similar promotional techniques: a bundle of two bottles without any price discount for Tropicana and Vitalia and a bundle of two bottles with a 50\% discount on the second bottle for Ariel and Dixan.

\subsection{Sample and procedure}

The study relies on a sample of 438 respondents recruited through a French online access panel hosted by research institute. The majority of this sample consists of women (77.2\%), and the mean age is 40 years. Each participant was randomly assigned to one of the six store flyer manipulations, such that 140 subjects reviewed the "no competing brands" condition $(N C), 145$ were exposed to the "two competing brands" condition (TC), and 153 saw the "four competing brands" condition $(F C)$. The order in which these consumers were exposed to the two target product categories was counterbalanced to minimize position bias. The instruction participants received was adapted from that provided by Pieters et al. (2007) in their experiment: "Page through the store flyer pages at your own pace, as you would do at home." It thus is relatively realistic. After exposure to the store flyer, similar to several other experiments dealing with competitive advertising (e.g., Keller, 1991; Kent and Allen, 1994), the respondents completed a distracter task to avoid their deliberate elaboration of the information and to maximize the probability that retrieval of information would involve long- 
term memory, as in real-life exposure to store flyers. The task consisted of answering questions about online shopping service. After finishing this task, respondents filled in the questionnaire about their intentions to visit the store and buy and completed items about the perceived variety of the retailer's assortment. They also answered a question about the number of brands they saw in each product category, to check the manipulation of the competitive advertising factor (Keller, 1987). Then they completed tasks pertaining to their target brand and promotional offer recognition. Finally, they reported the frequency of their purchases in the product class, product category involvement, store flyer proneness, and familiarity with the target brands, so we could check for the manipulation of the target brand familiarity factor.

\subsection{Measures}

3.4.1. Measures of memory. Memory is generally assessed with recall and recognition measures (Duke and Carlson, 1993). Recall evaluates the accessibility of information, whereas recognition measures awareness of having been exposed to a stimulus (Bagozzi and Silk, 1983; Kumar and Krishnan, 2004). There is significant debate among advertising researchers as to which type of memory measure is more accurate (Bagozzi and Silk, 1983; Singh et al., 1988). Previous literature has shown that recognition is less subject to random error than recall (Bagozzi and Silk, 1983), that memory traces do not appear with recall, and that recognition is more discriminating because it features greater variance than recall (Singh et al., 1988). What is more important is that when brand choice occurs at the point of purchase, people only need a recognition level of memory, because the store is full of cues that will help them activate their memory traces. In contrast, when the brand choice occurs at home, where most existing alternatives are not available, the consumer may need a higher recall level to access the information stored in memory (Bettman, 1979). Finally, in low 
involvement contexts or for low involvement convenience goods (as in the experimental manipulation), recognition is more relevant than recall with regard to memory effects (Krugman, 1977; Bettman, 1979; Kent and Allen, 1993). Consequently, we operationalize memory with recognition.

When the participants correctly identified the target brand as having been promoted in the store flyer, we coded brand recognition as 1 . If they failed to recognize the target brand, their brand recognition was coded as 0 . When respondents correctly matched the right promotion with the target brand, we coded the promotional offer recognition as 1 , whereas if they failed to match the right promotion with the target brand, promotional offer recognition equaled 0.

\subsubsection{Measures of perceived variety of the retailer's assortment and behavioral}

intentions. The measure of the perceived variety of the retailer's assortment came from Chowdhury et al. (1998, see Appendix 2). To measure intentions to visit the store and buy, we used two single-item measures, "After paging through this store flyer, I would like to visit this retailer's store" and "After paging out through this store flyer, I would like to buy some of the promoted products," with seven-point Likert scales $(1=$ totally disagree; $7=$ totally agree $)$.

3.4.3. Measures of the covariables. We also included four covariables: product category involvement, store flyer proneness, frequency of purchase of the product category, and product category class. Product category involvement and store flyer proneness were assessed on seven-point Likert scales (see Appendix 2) adapted from Strazzierri (1994) and Volle (1999), respectively. They proved unidimensional and reliable. To assess the frequency of product category purchases, we used a single item ("What is your frequency of purchasing [product category]?" with the responses: "Never," "Less than a once per month," "Once per 
month," and "Several times per month"). Finally, product category class used a dummy variable, with $1=$ juice and $2=$ detergent.

\section{Results}

We first conducted manipulation checks to verify the competitive advertising and brand familiarity manipulations. The subsequent analyses then test the hypotheses for manufacturers and retailers.

\subsection{Manipulation checks}

To check for the competitive advertising and target brand familiarity manipulations, we conducted an ANCOVA, with the number of brands respondents reported having seen as the dependent variable. We also included the four covariables.

4.1.1. Competitive advertising manipulation check. The results support the intended manipulation; respondents exposed to the no competing brand manipulation reported having seen fewer brands than those in the two and the four competing brand conditions $(N C=2.37$, $T C=3.36, F C=4.26 ; F=184.87, p<.0001)$. Nevertheless, it is worth noting that respondents reported having seen more brands in the "no competing brands" condition than they actually saw and fewer brands in the "four competing brands" condition. This finding is consistent with previous studies (e.g., Keller, 1987).

4.1.2. Target brand familiarity manipulation check. The results also support the brand familiarity manipulation. The scale of familiarity has a higher mean for familiar brands than for unfamiliar brands (familiar $=4.68$, unfamiliar $=1.53 ; F=469.11, p<.0001$ ).

\subsection{Manufacturer hypotheses}

Because brand and promotional offer recognition are nominal dependant variables, we use a logistic regression model to analyze the effect of competitive advertising on them. In this model, we again integrate the four covariables. 
4.2.1. Brand and promotional offer recognition. As we show in Table 2, the effect of competitive advertising on brand recognition is significant (Wald statistic $=3.84, p<.05$ ). Regarding the percentage of respondents who recognize the brand, we find that the level increases with the level of competitive advertising $(N C=33.9 \%, T C=44.8 \%, F C=50.7 \%$; $\left.\chi^{2}=17.02, p<.04\right)$. We predicted competitive advertising within store flyers would be detrimental for brand recognition, but the findings indicate the opposite. As for promotional offer recognition, the main effect of competitive advertising within store flyers is not significant $($ Wald statistic $=.10, p>.205)$. The frequency of recognition scores suggests that the respondents achieve very poor promotional offer recognition, regardless of the level of competitive advertising $\left(N=14.4 \%, T C=14.5 \%, F C=17.3 \% ; \chi^{2}=1.48, p>.15\right)$. Together these results cause us to reject $\mathrm{H} 1$.

[Insert Table 2 here]

\subsubsection{Moderating effect of brand familiarity. To test the moderating effect of brand} familiarity on recognition, we note the interaction effect in Table 2. For brand recognition, the interaction effect is not significant, though the results differ according to product category. For detergent, we find no significant interaction effect (Wald statistic $=.71, p>.399$ ), but the effect is significant for the juice product class (Wald statistic $=5.15, p<.023$ ). The percentages of respondents who recognize the unfamiliar juice brand are constant across the manipulation conditions $\left(N C=41.4 \%, T C=42.1 \%, F C=43.8 \% ; \chi^{2}=.66, p>.31\right)$. However, for the familiar juice brand, the frequency of recognition significantly increases with the level of competitive advertising $\left(N C=20 \%, T C=59.4 \%, F C=53.3 \% ; \chi^{2}=25.61\right.$, $p<.0001)$. We find similar results for the effect of competitive advertising on promotional offer recognition: no significant effect for detergent (Wald statistic $=.13, p>.714$ ) but 
significant effects for juice (Wald statistic $=4.31, p<.038$ ). Again, the results indicate that for the familiar brand, promotional offer frequency of recognition increases with the number of competing brands $\left(N C=5.7 \%, T C=7.2 \%, F C=16 \% ; \chi^{2}=5.08, p<.078\right)$. However, for the unfamiliar brand, there is no significant effect of competitive advertising on promotional offer recognition $\left(N C=12.9 \%, T C=17.1 \%, F C=9 \% ; \chi^{2}=2.25, p>.323\right)$. It seems evident that at a certain point (i.e., exposure to four competing brands), the effect of competitive advertising within store flyers becomes detrimental. Again, these results tend to support the idea of a positive link between competitive advertising and recognition, which implies positive effects for familiar brands, whose recognition of both the brand and the promotional offer improves when subjects view high levels of competitive advertising. Thus, $\mathrm{H} 2$ is not supported.

\subsection{Retailer hypotheses}

\subsubsection{Effect of competitive advertising on perceived variety of the retailer's}

assortment. We use the ANCOVA model to analyze the effects of competitive advertising on perceived variety of the retailer's assortment. Significant main effects reveal that evaluations of the retailer's assortment variety are higher when the respondents consider a high level of competitive advertising $(N C=4.59, T C=4.91, F C=5.05 ; F=4.59, p<.01)$. This finding is in line with our prediction in $\mathrm{H} 3$ and supports the idea that the participants use the number of brands as a salient cue, from which they infer the variety of the retailer's assortment.

\subsubsection{Mediating effect of perceived variety of the retailer's assortment. We conduct}

several linear regressions to determine if the perceived variety of the retailer's assortment might mediate the relationship between competitive advertising within store flyers and intention to visit the store or buy (Baron and Kenny, 1986). The findings reveal that the perceived variety of the retailer's assortment has significant effects on intention to visit the 
store and buy, in support of H4 (see regressions R3 and R6 in Table 3). They also show that competitive advertising has a significant direct effect on intentions to visit the store (R2), but this effect is not significant when we control for perceived variety of the retailer's assortment (R3). Therefore, perceived variety of the retailer's assortment totally mediates this relationship. Finally, competitive advertising has a significant direct effect on intention to buy (R4), even when we control for perceived variety of the retailer's assortment (R5). This latter is a quasi-mediator of the relationship between competitive advertising and intentions to buy. It also can be directly affected by the number of competing brands; intentions to buy from the retailer are higher among respondents who saw the competitive advertising than among those exposed to no competitive advertising $(N C=3.87, T C=4.00, F C=4.60 ; F=2.78, p<.045)$.

[Insert Table 3 here]

In summary, and contrary to our suppositions, competitive advertising within store flyers has no negative effect on brand recognition (H1a not supported); rather, brand recognition even increases when the consumers see more competing brands. Neither is promotional offer recognition affected by competitive advertising within store flyers (H1b not supported). Furthermore, for brands of juice, the beneficial effect of competitive advertising within store flyers is more important among familiar brands than unfamiliar brands ( $\mathrm{H} 2$ not supported). Finally, competitive advertising within store flyers enhances perceptions of the variety of the assortment (H3 supported), which totally or partially mediates the relationship between competitive advertising and intentions to visit the store or buy (H4 supported). We discuss these findings in greater depth next.

\section{Implications, limitations, and directions for further research}


The goal of this research has been to examine the effect of competitive advertising within store flyers on manufacturers and retailers. We hypothesized that this effect would be negative for the former (i.e., decreased memory performance for the brand and promotional offer) and positive for the latter (i.e., better perceptions of assortment variety, higher intentions to visit and buy). The experimental results reveal some surprising and challenging conclusions though. We confirm our rationale about retailers, in that we demonstrate competitive advertising improves perceptions of the variety of retailer's assortment, which has a positive impact on intentions to visit the store and buy. However, the findings in relation to the manufacturers do not support previous empirical results from advertising literature.

Specifically, we find that manufacturers' brands benefit from high levels of competitive advertising within store flyers; brand recognition increases when subjects examine store flyers that promote many competing brands on the same page. As we discussed in the conceptual section, consumers generally choose to be exposed to store flyers, such that they may be more involved in processing the information, which should increase their resistance to competitive advertising. Previous competitive advertising research mainly deals with traditional media (magazines, television), for which consumers have become quite sophisticated in avoiding ads through technology (e.g., remote control) or distractions during commercial breaks (Lee and Lee, 2007). This difference in processing goals may explain why brand recognition, in the case of store flyers, is resistant to the negative effect of competitive advertising. Moreover, while viewing the pages that promoted several competing brands, respondents may have associated this high variety with a good deal in the product class. Attracted by this signal effect, they may have examined the pages with more interest and treated the information more extensively, which resulted in their higher attention to the clutter. 
Competitive advertising within store flyers also affects promotional offer recognition, though the effect is not statistically significant. The promotional recognition scores increased with the competitive clutter. To explain this unexpected finding, we note that the store flyers in this study mainly communicate alignable and comparable attributes of the competing brands (i.e., monetary mechanisms). In the context of competitive advertising, alignable attributes induce better memory performance than do nonalignable attributes, because they serve as a frame of reference and facilitate information processing, encoding, and retrieval (Lee and Lee, 2007). However, the product pictures may have attracted consumers' attention while diverting their focus from the promotional offer itself, which might explain why the effect of competitive advertising on promotional offer recognition is not significant. People are generally more focused on the pictorial elements of an ad, compared with textual elements (Pieters et al., 2007). Furthermore, the level of promotional recognition is poor in all experimental conditions, regardless of the competitive clutter. This result is congruent with previous research that has demonstrated consumers do not process information about price and price promotions deeply. As an illustration, only $13 \%$ of consumers who have just put a product in their basket are able to report the price discount associated with it, and half of them are not even aware they had purchased the product at a lower price than the normal price (Dickson and Sawyer, 1990).

The study findings show that brand familiarity moderates competitive advertising effect. Although brand and promotional offer recognition for familiar brands increase with the number of competing brands, we find no significant effect for unfamiliar brands. As highlighted by previous research (e.g., Kent and Allen, 1994), known brands have a strong memory representation that gets strengthened by exposure to directly competing brands. However, this result should be interpreted with caution, because it is replicated only in the 
juice category. The two product categories are comparable in terms of product involvement (means $=4.11$ for juice and 4.1 for detergent; $\mathrm{t}=.07 ; p>.05)$, but they differ in their purchase frequency (means $=3.23$ and 2.66; $\mathrm{t}=9.7 ; p<.0001$ ). Thus, it appears purchase frequency may play a moderating role for the effect of competitive advertising within store flyers on memory for brand. Moreover, the effect of brand familiarity on brand recognition is not linear and declines when competitive advertising is high (i.e., four competing brands). This result suggests threshold effects that may affect the positive impact of competitive advertising.

Taken together, these findings offer several managerial implications for both manufacturers and retailers. Our study conclusions should reassure manufacturers and show them that investing in store flyers is cost effective, even in a cluttered environment. They also encourage manufacturers to promote their brands in thematic store flyers (e.g., "back to school," holiday), in which the likelihood of competing brands is very high. The clutter seems to catch people's attention, so it is more effective to invest in such store flyers. This investment is worth the money when it is allocated to familiar brands. However, for unfamiliar brands, even if they are not influenced by competitive advertising, manufacturers should resort to less cluttered media to earn a return on their promotion and highlight their distinctive attributes. Manufacturers also should recall that the likelihood of obtaining a distinctive presence inside the store declines when they promote their brands in highly cluttered store flyers. They thus confront a trade-off between better communication inside the store and better attention outside the store on a flyer.

If retailers want to promote perceptions of the variety of their assortment, it is poor practice to include too many product categories in their store flyers. They instead should 
increase the number of competing brands in a specific product category and use the number of competing brands as a cue to help consumers infer the assortment image of the store.

To answer the question we raise in this paper's title, competitive advertising within store fliers can be a win-win strategy for both retailers and manufacturers. Manufacturers often believe they do not obtain an equitable return for their own brands and tend to seek exclusive page layouts, which is very expensive. By showing that they benefit from competitive advertising, as do retailers, this study reinforces the conclusions offered by Pieters et al. (2007) and joins their call for closer collaboration between manufacturers and retailers.

The study also has some limitations that should be improved through further research. First, regarding the experimental design, we used online exposures, and subjects viewed the store flyers on a screen. This procedure is in line with previous research (e.g., Pieters et al., 2007) and aimed at facilitating the data collection. However, most store flyers are printed and received, whether at home or in newspapers. Further research should examine competitive advertising in real-life exposure conditions. Second, we focused only on the short-term effects of exposure to competitive advertising within store flyers. Although we tried to minimize this short-term bias by introducing a distracter task, the experimental procedure is not really reflective of a real-life exposure, and competitive advertising effects might differ over longer delays. It remains necessary to measure memory performance after a longer time interval after the exposure to competitive advertising. Third, the effect of competitive advertising might operate at two different times: at the moment of exposure and at the point of purchase. As a result, memory for the promoted brand might be positively or negatively affected not only by the presence of competing advertised brands but also by the atmosphere in the store (e.g., information about brands, aisle-end displays for specific promoted brands). We ignored this issue, which represents an important limitation of our study. Fourth, though we consider 
brand familiarity, more research is needed to understand its effect on competitive advertising within store flyers. Additional research might explore the effect of competitive advertising when the target brand is promoted with both well-known and less-known competing brands (Kent and Allen, 1994). Further research could also identify the boundary conditions of positive effects of competitive advertising. For example, store flyers' ad characteristics (size, color, location of the advertisement), the type of store flyers (online versus paper), and individual differences may affect consumers' memory for the brands advertised. Another important question pertains to the potential combined effects of competitive advertising due to brands and contextual elements, such as ad execution. Ads that offer similar features or pertain to directly competing brands might increase consumer confusion and thus lead to decreased memory. Finally, more insight is required to understand the effect of competitive advertising on retailers' performance, including sales and market share. 
Appendix 1: Example of an experimental condition (condition E)
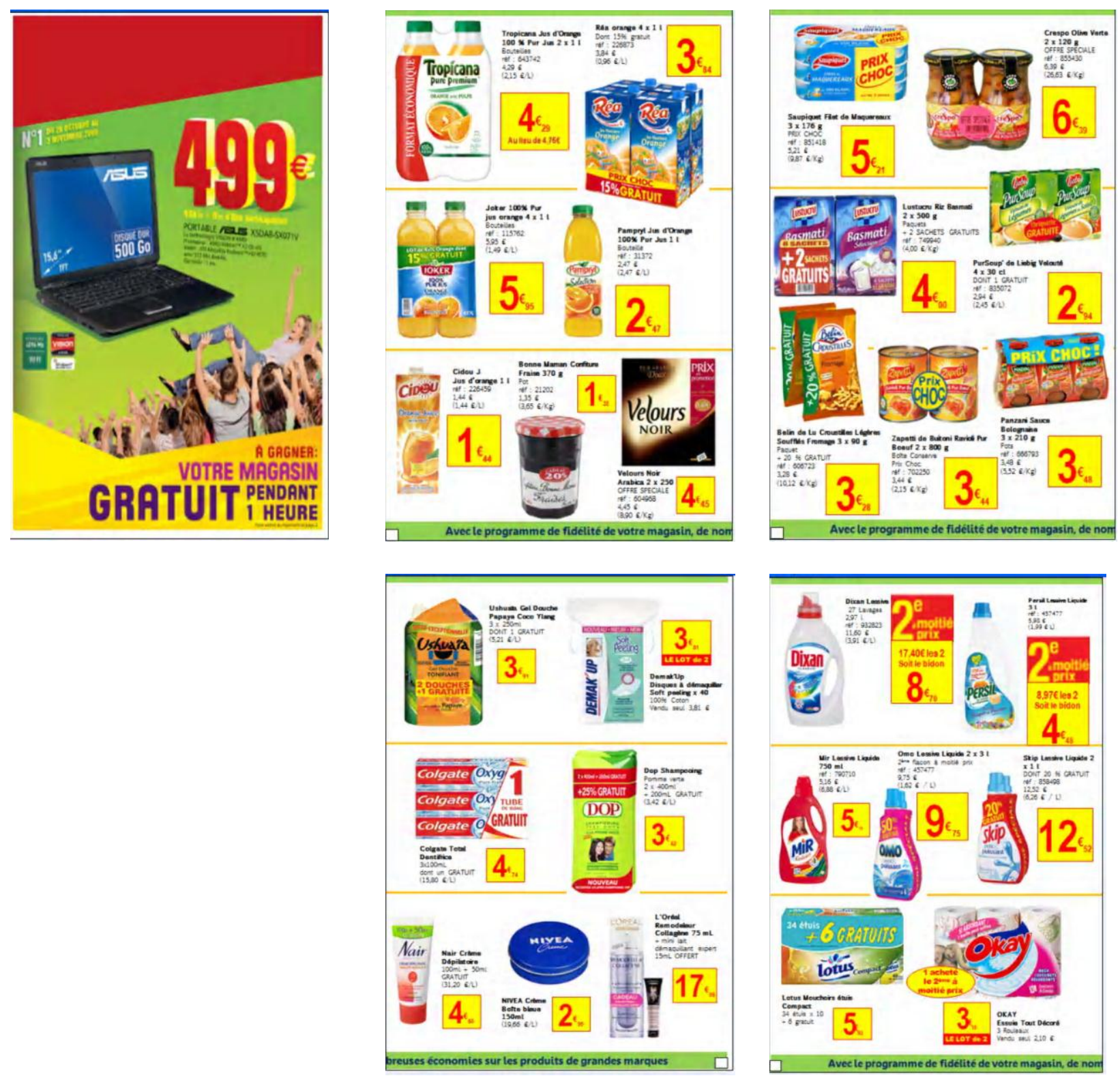
Appendix 2: Measures of continuous dependant variables and covariables

\begin{tabular}{|c|c|c|}
\hline Variable & Items & Reliability \\
\hline \multirow{3}{*}{$\begin{array}{l}\text { Perceived variety } \\
\text { of the retailer's } \\
\text { assortment }\end{array}$} & This store looks like it has a large variety of products. & \multirow{3}{*}{0.82} \\
\hline & Everything I need seems to be at this store. & \\
\hline & This store seems to have many brands. & \\
\hline \multirow{3}{*}{$\begin{array}{l}\text { Product category } \\
\text { involvement }\end{array}$} & <product category name> is an important category for me. & \multirow{3}{*}{0.85} \\
\hline & I find talking about < product category name > interesting. & \\
\hline & I enjoy buying <product category name>. & \\
\hline \multirow{3}{*}{$\begin{array}{l}\text { Store flyer } \\
\text { proneness }\end{array}$} & I'm interested in store flyers. & \multirow{3}{*}{0.88} \\
\hline & I carefully read store flyers to compare prices between stores. & \\
\hline & $\begin{array}{l}\text { Before shopping, I identify some products to buy once I'm in the } \\
\text { store. }\end{array}$ & \\
\hline
\end{tabular}




\section{References}

Alba, J.W., Hutchinson, J.W., 1987. Dimensions of consumer expertise. Journal of Consumer Research 13 (4), 411-53.

Arnold, S.J., Kozinets, R.V., Handelman, J.M., 2001. Hometown ideology and retailer legitimation: the institutional semiotics of Wal-Mart flyers. Journal of Retailing 77 (2), 243271.

Aubril, S., Puget, Y., 2007. Le dictionnaire de la distribution, fourth edition. Paris: LSA.

Baron, R.M., Kenny, D.A., 1986. The moderator-mediator variable distinction in social psychological research: conceptual, strategic and statistical consideration. Journal of Personality and Social Psychology 51 (6), 1173-1182.

Bagozzi, R.P., Silk, A., 1983. Recall, recognition, and the measurement of memory for print advertisements. Marketing Science 2 (2), 95-134.

Bettman, J.R., 1979. Memory factors in consumer choice: a review. Journal of Marketing 43 (2), 37-53.

Blattberg, R.C., Neslin, S.A., 1990. Sales promotion-Concepts, methods, and strategies. Englewood Cliffs, NJ: Prentice Hall.

Bodapati, A.V., Srinivasan., 2006. The impact of feature advertising on customer store choice. Working paper, Stanford Graduate School of Business, Proceedings, 1-44.

Boatwright, P., Nunes, J., 2001. Reducing assortment: an attribute-based approach. Journal of Marketing 65 (3), 50-63.

Broniarczyk, S., Hoyer, W., McAlister, L.,1998. Consumers perceptions of the assortment offered in a grocery category: the impact of item reduction. Journal of Marketing Research $35(2), 166-176$. 
Burke, R.R., Srull, T.K., 1988. Competitive interference and consumer memory for advertising. Journal of Consumer Research 15 (1), 55-68.

Burton, S., Lichtenstein, D.R., Netemeyer, R.G., 1999. Exposure to sales flyers and increased purchases in retail supermarkets. Journal of Advertising Research 39 (5), 7-14.

Chandon, P., Wansink, B., Laurent, G., 2000. A benefit congruency framework of sales promotion effectiveness. Journal of Marketing, 64 (4), 65-81.

Chowdhury, J., Reardon, J., Srivastasa, R., 1998. Alternatives modes of measuring store image: an empirical assessment of structured versus unstructured measures. Journal of Marketing Theory and Practice 6(2), 72-86.

Danaher, P., 2008. The effect of competitive advertising interference on sales for packaged goods. Journal of Marketing Research 45 (2), 211-225.

Dickson, P.R., Sawyer, A.G. 1990. The price knowledge and search of supermarket shoppers. Journal of Marketing 54 (3), 42-53.

Duke, C.R., Carlson, L., 1993. A conceptual approach to alternative memory measures for advertising effectiveness. Journal of Current Issues and Research in Advertising 15 (2), 114.

Gijsbrehts, E., Campo, K., Goossens, T., 2003. The impact of store flyers on store traffic and store sales: a geo-marketing approach. Journal of Retailing 79 (1), 1-16

Van Harpen, E., Pieters, R., 2002. The variety of an assortment: an extension to the attributebased approach. Marketing Science 21 (3), 331-341.

Kahn, B., and Wansink, B., 2004. The influence of assortment structure on perceived variety and consumption quantities. Journal of Consumer Research 30 (4), 519-533.

Keller, K.L., 1987. Memory factors in advertising: the effects of advertising retrieval cues on brand evaluations. Journal of Consumer Research 14 (3), 316-333. 
Keller, K.L., 1991. Memory and evaluation effects in competitive advertising environments. Journal of Consumer Research 17 (4), 463-476.

Kent, R.J., Allen, C.T., 1993. Does competitive clutter in television advertising "interfere" with the recall and recognition of brand names and ad claims. Marketing Letters 4 (2), 175184.

Kent, R.J., Allen, C.T., 1994. Competitive interference effects in consumer memory for advertising: the role of brand familiarity. Journal of Marketing 58 (3), 97-105.

Kent, R.J, Kellaris, J.J., 2001. Competitive interference effects in memory for advertising: are familiar brands exempt? Journal of Marketing Communications 7 (3), 159-169.

Krugman, H.E., 1977. Memory without recall, exposure without perception. Journal of Advertising Research, 17 (8), 7-12.

Kumar, A., 2000. Interference effects of contextual cues in advertisements on memory for ad content. Journal of Consumer Psychology 9 (3), 155-166.

Kumar, A., Krishnan, S., 2004. Memory interference in advertising: a replication and extension. Journal of Consumer Research 30 (4), 602-611.

Laroche, M., Cleveland, M., Maravelakis, I., 2006. Competitive advertising interference and ad repetition effects: comparing high-share and low-share brands. International Journal of Advertising 25 (3), 271-307.

Lee, B.K., W.N., Lee, 2007. Decreasing advertising interference: the impact of comparable differences on consumer memory in competitive advertising environments. Psychology and Marketing 24 (11), 919-945.

Leterrier, J.P., 2003. La communication promotionnelle des distributeurs par prospectus. $6^{\text {ème }}$ Colloque Etienne Thil, 25 and 26 Septembre, La Rochelle. 
Miranda, M.J., Konya, L., 2007. Directing store flyers to the appropriate audience. Journal of Retailing and Consumer Services 14 (3), 175-181.

Moriarty, M., 1983. Feature advertising-price interaction effects in the retail environment. Journal of Retailing 59 (2), 80-98.

Oppewal H. and Timmermans H. 1997. Retailer self-perceived store image and competitive position. International Review of Retail, Distribution and Consumer Research 7 (1), 41-59.

Pan, Y., Zinkhan, G.M., 2006. Determinants of retail patronage: a meta-analytical perspective. Journal of Retailing 82 (3), 229-243.

Pieters, R., Wedel, M., Zhang., J., 2007. Optimal feature advertising design under competitive clutter. Management Science 53 (11), 1815-1828.

Singh, S.N., Rothschild. M.L., Churchill. G.A. JR., 1988. Recognition versus recall as measures of television commercials forgetting. Journal of Marketing Research 25 (1), 7280.

Strazzieri, A., 1994. Mesurer l'implication durable vis-à-vis d'un produit indépendamment du risque perçu. Recherche et Applications en Marketing 9 (1), 73-91.

Tversky, A., Kahneman, D., 1974. Judgment under uncertainty: heuristics and biases. Science, 185 (4157), 1124-1131.

Volle, P., 1999. Promotion et choix du point de vente. Collection Fnege, Vuibert, Paris.

Volle, P., 2001. The short-term effect of store-level promotions on store choice, and the moderating role of individual variables. Journal of Business Research 53, 63-73.

Zhang, J., Wedel, M., Pieters, R. 2009. Sales effects of attention to feature advertisements: a Bayesian mediation analysis. Journal of Marketing Research 46 (5), 669-681. 
Table 1. Experimental design

\begin{tabular}{cccc}
\cline { 2 - 4 } & & \multicolumn{2}{c}{ Familiarity with the target brand } \\
\cline { 2 - 4 } & & Familiar & Unfamiliar \\
\hline \multirow{2}{*}{$\begin{array}{c}\text { Number of competing } \\
\text { brands }\end{array}$} & 0 & Condition A & Condition B \\
\cline { 2 - 4 } & 2 & Condition C & Condition D \\
\hline
\end{tabular}


Table 2. Tests of hypotheses about the effect of competitive advertising within store flyers on brand and promotional offer recognition

\begin{tabular}{|c|c|c|c|c|c|c|}
\hline & \multicolumn{3}{|c|}{$\begin{array}{l}\text { Regression 1: Effect of the number } \\
\text { of competing brands on brand } \\
\text { recognition }\end{array}$} & \multicolumn{3}{|c|}{$\begin{array}{l}\text { Regression 2: Effect of the number of } \\
\text { competing brands on promotional offer } \\
\text { recognition }\end{array}$} \\
\hline & B & Wald & Sig. & B & Wald & Sig. \\
\hline Constant & -.85 & 3.65 & .05 & -2.67 & 17.79 & .000 \\
\hline $\begin{array}{c}\text { Number of competing } \\
\text { brands } \\
\end{array}$ & .23 & 3.84 & .05 & -.05 & .10 & .749 \\
\hline Product category & -.05 & .11 & .73 & .56 & 6.84 & .009 \\
\hline Store flyer proneness & .10 & 5.22 & .02 & .00 & .00 & .939 \\
\hline $\begin{array}{c}\text { Product category } \\
\text { involvement }\end{array}$ & -.06 & 1.54 & .21 & -.01 & .02 & .864 \\
\hline $\begin{array}{c}\text { Product category frequency } \\
\text { of purchase }\end{array}$ & .06 & .42 & .51 & .05 & .16 & .681 \\
\hline Familiarity with target brand & -.32 & 1.53 & .21 & -.76 & 3.52 & .060 \\
\hline $\begin{array}{c}\text { Interaction effect } \\
\text { (familiarity } \times \text { number of } \\
\text { competing brands) } \\
\end{array}$ & .22 & 1.49 & .22 & .58 & 4.54 & .033 \\
\hline
\end{tabular}


Table 3. Test of hypotheses about the mediating effect of perceived variety of the retailer's assortment

\begin{tabular}{|c|c|c|c|c|c|c|c|c|c|}
\hline & \multicolumn{9}{|c|}{ Mediating effect on intention to visit } \\
\hline & \multicolumn{3}{|c|}{$\begin{array}{l}\text { R1: Dependant variable: } \\
\text { Intention to visit }\end{array}$} & \multicolumn{3}{|c|}{$\begin{array}{l}\text { R2: Dependant variable: } \\
\text { Intention to visit }\end{array}$} & \multicolumn{3}{|c|}{$\begin{array}{l}\text { R3: Dependant variable: } \\
\text { Perceived variety of the } \\
\text { retailer's assortment }\end{array}$} \\
\hline & $\bar{\beta}$ & t & Sig. & $\beta$ & t & Sig. & B & $\mathrm{t}$ & Sig. \\
\hline Constant & .42 & 1.45 & .147 & 4.09 & 29.92 & .000 & 4.65 & 49.13 & .000 \\
\hline $\begin{array}{c}\text { Number of } \\
\text { competing brands }\end{array}$ & .02 & .31 & .754 & 19 & 1.91 & .05 & .21 & 3.01 & . 003 \\
\hline $\begin{array}{l}\text { Perceived variety } \\
\text { of the retailer's } \\
\text { assortment }\end{array}$ & .78 & 13.62 & .000 & ------ & ------ & ------ & ------ & ------ & ------ \\
\hline
\end{tabular}

\begin{tabular}{|c|c|c|c|c|c|c|c|c|c|}
\hline & \multicolumn{9}{|c|}{ Mediating effect on intention to buy } \\
\hline & \multicolumn{3}{|c|}{$\begin{array}{l}\text { R4: Dependant variable: } \\
\text { Intention to buy }\end{array}$} & \multicolumn{3}{|c|}{$\begin{array}{l}\text { R5: Dependant variable: } \\
\text { Intention to buy }\end{array}$} & \multicolumn{3}{|c|}{$\begin{array}{l}\text { R6: Dependant variable: } \\
\text { Perceived variety of the } \\
\text { retailer's assortment }\end{array}$} \\
\hline & $\beta$ & $\bar{t}$ & Sig. & $\bar{\beta}$ & $\bar{t}$ & Sig. & B & t & Sig. \\
\hline Constant & .15 & .52 & .604 & 3.7 & 27.79 & .000 & 4.65 & 49.13 & .000 \\
\hline $\begin{array}{c}\text { Number of } \\
\text { competing brands }\end{array}$ & .19 & 2.25 & .025 & ------- & 3.55 & .000 & .21 & 3.01 & .003 \\
\hline $\begin{array}{l}\text { Perceived variety } \\
\text { of the retailer's } \\
\text { assortment }\end{array}$ & .78 & 13.48 & .000 & ------- & ------- & ------ & ------- & ------- & \\
\hline
\end{tabular}

